\title{
MANAJEMEN KELAS DALAM PEMBELAJARAN AL-QURAN METODE UMMI DI MTS SUNAN DRAJAT BANJARWATI PACIRAN LAMONGAN
}

\author{
Rizqa Yuhda Rohmah 1) \\ UIN Pasca Maulana Malik Ibrahim Malang, Indonesia \\ Email: rizqayuhda@gmail.com
}

\begin{abstract}
Abstrak : MTs Sunan Drajat Banjarwati Paciran Lamongan merupakan salah satu lembaga yang terletak pada naungan Pondok Pesantren Sunan Drajat yang memiliki program pembelajaran Al-Quran metode Ummi. Untuk mencetak generasi Qurani yang baik maka perlu adanya manajemen kelas untuk menciptakan kondisi kelas yang kondusif, guna mengatasi kendala-kendala dalam belajar peserta didik. Maka untuk mendeskripsikan bagaimana implementasi dalam pembelajaran Al-Quran metode Ummi maka dilakukan penelitian ini. Tujuan penelitian 1) Bagaimana manajemen kelas dalam pembelajaran AlQuran metode Ummi di MTs Sunan Drajat Banjarwarti Paciran Lamongan? 2) Bagaimana problematika dan solusi manajemen kelas dalam pembelajaran Al-Quran metode Ummi di MTs Sunan Drajat Banjarwati Paciran Lamongan? penelitian ini merupakan penelitian kualitatif yang menghasilkan data dan dianalisis dengan menggunakan metode deskriptif yang disesuaikan dengan pembelajaran Al-Quran metode Ummi di MTs Sunan Drajat Banjarwati Paciran Lamongan. Data yang dihimpun menggunakan teknik wawancara, observasi dan dokumentasi hasil penelitian manajemen kelas dalam pembelajaran Al-Quran metode ummi sebagai berikut 1). Perencanaan guru menyiapkan PROTA (Program Tahunan) dan PROMES (Program Semester), pengelompokan kelas di awal saat PPDB (Penerimaan Peserta Didik Baru) dengan adanya Pre Test, mengenai pelaksanaannya guru menyesuaikan dengan 7 tahapan yang telah di tetapkan oleh guru, pengevaluasian ada beberapa evaluasi penilaian saat pembelajaran berlangsung, saat UAS (Ujian Akhir Sekolah) dan UTS (Ujian Tengah Semester) kenaiakn Jilid terakhir Imtihan dan Khotmil. 2). Problematikan dan solusi yaitu: kurangnya guru dalam pembelajaran, kedisiplinan peserta didik dengan solusi harus berani menambah 2 kali lipat guru saat pembelajaran berlangsung dan dengan adanya guru yang bersertifikasi, mengikuti Tahsin satu bulan sekali.
\end{abstract}

Kata kunci: Manajemen Kelas, Pembelajaran Al-Quran, metode Ummi.

\begin{abstract}
MTs Sunan Drajat Banjarwati Paciran Lamongan is one of the institutions located under the auspices of the Sunan Drajat Islamic Boarding School which has an Ummi method of learning Al-Quran learning program. To produce a good Quranic generation, it is necessary to have class management to create conducive classroom conditions, in order to overcome obstacles in student learning. So to describe how the implementation of the Ummi method in learning Al-Quran, this research was carried out. Research objectives 1) How is classroom management in the Ummi method of learning AlQuran at MTs Sunan Drajat Banjarwarti Paciran Lamongan? 2) What are the problems and solutions for classroom management in the Ummi method of learning Al-Quran at MTs Sunan Drajat Banjarwati Paciran Lamongan? This research is a qualitative research that produces data and is analyzed using a descriptive method that is adapted to the Ummi method of learning Al-Quran at MTs Sunan Drajat Banjarwati Paciran Lamongan. The data
\end{abstract}


collected using interview techniques, observation and documentation of the results of classroom management research in Al-Quran learning the ummi method as follows 1). Teacher planning to prepare PROTA (Annual Program) and PROMES (Semester Program), class grouping at the beginning of PPDB (New Student Admission) with the Pre-Test, regarding the implementation the teacher adjusts to the 7 stages that have been set by the teacher, evaluating there are several evaluations assessment during learning takes place, when UAS (School Final Examination) and UTS (Middle Semester Examination) increase in the last volume of Imtihan and Khotmil. 2). The problems and solutions are: lack of teachers in learning, student discipline with solutions must be brave to add 2 times more teachers during learning and with certified teachers, take Tahsin once a month.

Keywords: Class Management, Al-Quran Learning, Ummi method.

\section{Pendahuluan}

Untuk meningkatkan mutu pendidikan diperlukan peningkatan dan penyempurnaan pendidikan, yang berkaitan erat dengan peningkatan mutu proses belajar mengajar secara operasional yang berlangsung di dalam kelas. Oleh karena itu, diperlukan manajemen kelas yang baik sehingga tujuan pembelajaran dapat tercapai. Karenanya, manajemen kelas memegang peran yang sangat menentukan dalam proses belajar mengajar. Manajemen kelas menurut Sunaryo adalah masalah tingkah laku yang kompleks, dan guru menggunakannya untuk menciptakan dan mempertahankan kondisi kelas sedemikian rupa, sehingga siswa dapat mencapai tujuan pengajaran secara efesien dan memungkinkan mereka dapat belajar. ${ }^{1}$ Ketika terjadi proses pembelajaran, banyak hal yang harus diperhatikan guru. Berbeda jumlah dan karakteristik peserta didik, berbeda pula cara pengelolaannya. ${ }^{2}$

Pengelolaan kelas merupakan sekumpulan perilaku kompleks yang digunakan guru untuk menciptakan dan memelihara kondisi kelas sehingga peserta didik dapat mencapai tujuan pembelajaran secara efesien. ${ }^{3}$ Konsep manajemen kelas adalah bahwa berbagai jenis kegiatan yang dengan sengaja dilakukan oleh guru dengan tujuan menciptakan kondisi optimal bagi terjadinya proses belajar mengajar di kelas. ${ }^{4}$ Secara garis besar, perkembangan teori manajemen yang umumnya dikenal dalam teori manajemen kontemporer disajikan dalam tebel berikut: 1) Pendekatan kekuasaan, 2) Pendekatan Ancaman, 3) pendekatan kebebasan, dan 4) Pendekatan Resep. ${ }^{5}$ Keberhasilan manajemen kelas dalam dalam memberikan dukungan terhadap pencapaian tujuan pembelajaran, oleh berbagai faktor yaitu lingkunagn fisik, kondisi sosio-emosional, dan kondisi organisasional. ${ }^{6}$

Pembelajaran merupakan suatu sistem instruksional mengacu pada pengertian sebagai seperangkat komponen, antara lain tujuan, bahan atau materi, guru, siswa, metode, alat dan penilaian atau evaluasi. Agar tujuan tercapai, semua komponen yang ada harus diorganisasikan sehingga antar sesama komponen terjadi kerja sama. Karena itu guru tidak boleh hanya memperhatikan komponen-komponen tertentu saja misalnya metode, bahan dan evaluasi saja tapi ia harus memperhatikan komponen secara

\footnotetext{
${ }^{1}$ Sunaryo, Strategi Belajar Mengajar Ilmu Pengetahuan Sosial (Malang: IKIP Malang, 1989), 62.

2 Sudarwan danim dan Yunan Danim, Administrasi Sekolah dan Manajemen Kelas (Bandung: Pustaka Setia, 2010$), 165$.

${ }^{3}$ Erwin Widiasworo, Cerdas Pengelolaan Kelas (Yogyakarta: DIVA Press, 2018), 12.

${ }^{4}$ Faizal Djabidi, Manajemen Pengelolaan Kelas (Malang: Madani, 2016), 39.

5 Euis Karwati and Donni Juni Priansa, Manajemen Kelas (Classroom Management) Guru Profesional yang Inspiratif, Kreatif, Menyenangkan, dan Berprestasi (Bandung: Alfabeta, 2014), 7-8.

${ }^{6}$ Kompri, Manajemen Sekolah: Teori dan Praktik (Bandung: Alfabeta, 2014), 143.
} 
keseluruhan. ${ }^{7}$ Lafadz Al-Quran secara Bahasa sama dengan Qira'ah yaitu akar kata dari Qara'a, qira'atan wa qur'anan, ia merupakan bentuk mashdar menurut wazan dari kata fu'lan,seperti qufran dan syukron. Bentuk kata kerjannya adalah qara'a yang berarti mengumpulkan dan menghimpun. ${ }^{8}$ Pada pertengahan tahun 2007, KPI (Konsorsium Pendidikan Islam) telah menerbitkan sebuah metode baca tulis AlQuran yang bernama Ummi. Metode ini disusun oleh masruri dan A. Yusuf MS. Sebelum beredar di masyarakat, buku ini telah melewati beberapa tim penguji pentashih. Antara lain, Roem Rowi, yang merupakan guru besar Ulumul Qur'an / tafsir Al-Quran IAIN Sunan Ampel Surabaya. Pentashih selanjutnya adalah Mudawi Ma'arif (al-Hafizh). Beliau pemegang sanad Muttashil sampai Rasulullah saw. Qira'ah Riwayat Hafs dan Qira'ah 'Asyarah.'

Metode Ummi tidak sekedar memberikan pembelajaran mengenai cara membaca Al-Quran yang baik dan benar. Metode Ummi menggunakan pendekatan dalam pengajarannya dan menggunakan nada-nada dalam membaca Al-Quran sehingga membuat anak-anak menjadi senang dan nyaman selain itu juga melalui metode Ummi setiap guru mampu memahami metodologi pelajaran Al-Quran dan tahapan-tahapannya serta manajemen kelas yang baik. Program pembelajaran Al-Quran metode Ummi ini setiap tahun semakin meningkat dari pembelajaran tingkat Jilid sampai dengan Tajwid, Ghorib, AlQuran bahkan sampai siswa yang tahfidz dan adanya munaqosah bagi peserta didik yang lulus tes membaca Al-Quran metode Ummi. Dalam satu kelas peserta didik dibagi menjadi 2 kelompok berdasarkan kemampuan peserta didik dalam membaca Al-Quran metode Ummi. Pembagian tersebut terdiri dari peserta didik yang kurang lancer dalam membaca Al-Quran dan yang sudah lancar membaca Al-Quran. ${ }^{10}$

Pembelajaran Al-Quran Metode Ummi ini dibagi menjadi 2 kali pertemuan dalam satu minggu. Dimulai dari guru memberikan contoh kepada peserta didik melalui alat peraga, setoran hafalan suratsurat pendek, peserta didik membaca ayat suci Al-Quran disimak oleh guru dan guru memberikan penilaian didalam buku prestasi peserta didik. Untuk mencetak generasi Qurani yang baik maka perlu adanya manajemen kelas untuk menciptakan kondisi kelas yang kondusif, guna mengatasi kendalakendala dalam belajar peserta didik. ${ }^{11}$

\section{Metode Penelitian}

Penelitian ini menggunaan penelitian deskriftif dengan model Pendekatan dan Jenis Penelitian, Penelitian ini menggunakan penelitian kualitatif ${ }^{12}$ penjelasan dari Jane Richie. ${ }^{13}$ Dilakukannya dengan menempuh langkah pengumpulan data, klasifikasi, dan analisis data, interpretasi, membuat kesimpulan dan laporan. ${ }^{14}$ Lokasi Penelitian, lokasi peneliti terfokus terhadap Manajemen Kelas dalam pembelajaran

\footnotetext{
7 Syaiful Bahri Djamarah dan Aswan Zain, Strategi Belajar Mengajar (Jakarta: Rineka Cipta, 2002), 10.

8 Manna' Al-Qaththanan, Pengantar Studi Ilmu Al-Quran, Terj. Mubabits fi 'Ulumil Qur'an oleh Aunur rafiq El-Mąni (Jakarta: Pustaka al-kautsar, 2006), 12.

${ }^{9}$ Mansyuri dan A. Yusuf, Belajar Mudah Membaca Al-Quran Ummi (Surabaya: KPI, 2007), 4.

${ }_{10}$ Alfi Mufidah Ishari, Wawancara, Pondok Pesantren Putri Sunan Drajat, Tgl 23 Juli 2020, Pada 18.30 WIB.

${ }^{11}$ Ibid., Ishari, Wawancara.

${ }^{12}$ Lexi J. Moleong, Metodologi Penelitian Kualitatif Edisi Revisi (Bandung: PT Remaja Rosdakarya, 2016), 6

13 Jane Richie, penelitian kualitatif adalah upaya untuk menyajikan dunia sosial, dan prespektifnya di dalam dunia, dari segi konsep, perilaku, persepsi dan persoalan tentang manusia yang diteliti.

${ }^{14}$ Nana Syaodih Sukmadinata, Metode Penelitian Pendidikan (Bandung: Remaja Rosdakarya, 2007), 76

137 | MUDIR: Jurnal Manajemen Pendidikan
} 
Al-Quran metode Ummi di MTs Sunan Drajat Banjarwati Paciran Lamongan. ${ }^{15}$ Pola dari penelitian ini bertujuan untuk mengetahui tentang fenomena yang terjadi dilapangan yang dikaji dengan menggunakan pendekatan kualitatif yang berinstrumenkan observasi, ${ }^{16}$ wawancara ${ }^{17}$ dan dokumentasi. ${ }^{18}$ Serta menggambarkan keadaan yang terjadi pada proses manajemen kelas pada pembelajaran metode Ummi di MTs Sunan Drajat Banjaranyar Paciran Lamongan. Dan yang terakhir yaitu teknik analisis data, Teknik analisis data yang digunakan dalam penelitian kualitatif mencakup transkip hasil wawancara, reduksi data, ${ }^{19}$ dalam pengertian mengenai reduksi data ${ }^{20}$ penyajian data, ${ }^{21}$ dari penjelasan yang dijelaskan oleh Miles dan Huberman ${ }^{22}$ penarikan kesimpulan. ${ }^{23}$ Dari pengertian yang sama di jelaskan oleh Miles dan Huberman mengenai tekhnik analisis data bagian akhir penarikan kesimpulan. ${ }^{24}$

\section{Findings and Discussion}

1. Manajemen Kelas dalam pembelajaran Al-Quran metode Ummi di MTs Sunan Drajat Banjarwati Paciran Lamongan.

manajemen kelas diserahkan langsung kepada guru lembaga atau pendidik yang mengajar di kelas, bagaimana cara guru untuk mengoperasikan peserta didik agar menciptakan suasana yang tenang ketika pembelajaran berlangsung karena setiap guru atau pendidik mempunyai kriteria yang berbeda dalam memanajemen kelas tersebut, adapun yang harus dilaksanakan dalam kelas yaitu do'a bersama sebelum pembelajaran dan juga adanya pembacaan surat-surat pendek yakni Juz 30 secara bersama

15 Manajemen Kelas dalam Pembelajaran Al-Quran, merupakan Upaya atau sebuah proses yang dilakukan oleh pihak madrasah untuk mengelola kelas dengan sedemikian rupa agar menjadi sebuah madrasah yang lebih baik dan mempunyai sikap yang berakhlaqul karimah.

${ }^{16}$ Metode observasi adalah studi yang disengaja dan sistematis tentang fenomena-fenomena sosial, dan gejala-gejala alam dengan jalan pengamatan dan pencatatan. Di dalam pengertian psikologik, observasi meliputi kegiatan pemusatan perhatian terhadap suatu obyek dengan menggunakan seluruh alat indera, baik itu melalui pengelihatan, penciuman, pendengaran, peraba, dan pengecap. Dalam artian penelitian observasi dapat dilakukan dengan tes, kuesioner, rekaman gambar, maupun rekaman suara.

17 Wawancara dilakukan oleh dua pihak, yaitu pewawancara (interviewer) yang mengajukan pertanyaan dan yang diwawancarai (informa) yang memberikan jawaban atas pertanyaan itu.

${ }^{18}$ Dokumentasi berasal dari kata dokumen, yang berarti barang-barang tertulis. Maka, metode dokumentasi dapat dikatakan sebagai teknik pengumpulan data dengan cara mencari data mengenai hal-hal atau variabel yang berupa transkrip, bukubuku, majalah, dokumen, surat kabar, prasasti, notulen rapat, catatan harian, dan sebagainya.

${ }^{19}$ Umarti, Hengki Wijaya, Analisis Data Kualitatif Teori Konsep dalam Penelitian Pendidikan, (Makassar: Sekolah Tinggi Theologia Jaffray, 2020), 105.

${ }_{20}$ Dalam pengumpulan data penelitian kualitatif peneliti menggunakan berbagai macam tekhnik dan berlangsung secara berulang-ulang sehingga diperoleh dalam data sangat banyak dan kompleks. Fokus penelitian pada data tersebut mengenai manajemen kelas dan problematika yang terjadi ketika pembelajaran Al-Qur'an metode Ummi.

${ }^{21}$ Mardawani, Praktis Penelitian Kualitatif Teori Dasar dan Analisis Data dalam Prespektif Kualitatif, (Yogyakarta, CV Budi Utama, 2020), 67-68.

22 Miles dan Huberman menyatakan, "the most frequent from of display data for qualitative reserch data intabune past narrative tex" yang paling sering digunakan untuk menyajiakn data dalam penelitian kualitatif adalah dengan teks yang bersifat naratif, Miles dan Huberman membatasi suatu "penyajian" sebagai sekumpulan informasi tersusun yang memberi kemungkinan adanya penarikan kesimpulan dan pengembalian Tindakan. salama penelitian di MTs Sunan Drajat Banjarwati Paciran Lamongan yang mana data tersebut yang akan memberikan kemungkinan untuk ditarik kesimpulan.

${ }^{23}$ Mardawani, Praktis Penelitian..., 68.

${ }^{24}$ Miles dan Huberman, penarikan kesimpulan atau verifikasi merupakan Langkah ketiga dari analisis data kualitatif, karena kesimpulan awal yang dikemukakan masih bersifat sementara, dan mungkin akan berubah bila tidak ditemukan bukti-bukti yang kuat yang mendukung pada tahap pengumpulan data berikutnya, tapi apabila kesimpulan yang dikemukakan ditahap awal, di dukung oleh bukti yang kuat, maka kesimpulan yang dikemukakan merupakan kesimpulan yang kredibel dan dapat digunakan. Proses ini yang mampu menggambarkan manajemen kelas dalam pembelajaran Al-Quran metode Ummi. 
dengan khatam dalam jangka waktu 15 hari karena di MTs Sunan Drajat Banjarwati Paciran Lamongan pembelajaran Al-Quran menjadi sebuah program unggulan. Untuk manajemen kelas dalam pembelajaran Al-Quran metode Ummi di MTs Sunan Drajat Banjarwati Paciran Lamongan menggunakan manajemen kelas gerak yang mana kelas gerak ini merupakan kelas yang pembelajarannya beda dengan mata pelajaran umum karena kelas ini berjalan terus siapa yang cepat dalam lulus maka dia yang akan naik Jilid kalaupun ada peserta didik yang tidak bisa di tinggal tetapi ada jam tambahan untuk peserta didik yang tertinggal dalam pembelajaran tersebut setelah jam pelajaran di madrasah selesai. Terkait implementasinya sebagai berikut:

a. Tahap Perencanaan pembelajaran Al-Quran metode Ummi di MTs Sunan Drajat Banjarwati Paciran Lamongan.

Dari perencanaan pohak lembaga mempunyai target yang jelas dalam pembelajaran Al-Quran nya yang dimulai dari kelas 7 (Tujuh) untuk harus selesai dalam pembelajaran Al-Quran Jilid 1 (Satu), 2 (Dua), dan 3 (Tiga) dan dilakukan satu minggu dua kali masuk kelas dan satu kelas juga di bagi menjadi dua kelompok karena agar memudahkan guru atau pendidik dalam memberikan sebuah materi kepada peserta didik yang bertempat satu kelompok tetap di dalam kelas dan yang satu kelompok lagi berada di ruangan khusus pembelajaran Al-Quran metode Ummi, selanjutnya untuk kelas 8 (Delapan) peserta didik harus selesai Al-Quran, Tajwid dan Ghoribnya, dan untuk yang kelas 9 (Sembilan) semester Ganjil adalah Munaqosyah sampai Khotaman dan Imtihan Ummi MTs Sunan Drajat Banjarwati Paciran Lamongan.

b. Implementasi Pembelajaran Al-Quran Metode Ummi di MTs Sunan Drajat Banjarwati Paciran Lamongan. Pelaksanaan manajemen kelas dalam pembelajaran Al-Quran metode Ummi di MTs Sunan Drajat Banjarwati Paciran Lamongan sudah terlaksana dengan baik karena bisa meluluskan peserta didik 85\% dari peserta didik keseluruhan, untuk pembelajarannya menggunakan metode klasikal baca simak murni dan klasikal baca simak yang di mulai dari guru memberikan contoh terlebih dahulu kepada peserta didik selanjutnya dibaca oleh peserta didik dan yang lainnya menyimak peserta didik yang membaca. Selanjutnya cara untuk tahapan dalam pembelajaran AlQuran metode Ummi yang pertama dimulai dari pembukaan yang meliputi guru untuk mempersiapkan peserta didik untuk duduk later "U" selanjutnya apersepsi yaitu mengulang materi sebelum masuk materi yang baru setelah itu memberikan pemahaman kepada peserta didik, selanjutnya dengan pemahaman konsep yang artinya guru mengulang-ulang contoh yang di bawah pokok bahasan dan ada juga peserta didik yang mencari contoh tersebut setelah itu latihan atau keterampilan yaitu peserta didik membaca yang lainnya menyimak bacaan peserta didik yang membaca, selanjutnya evaluasi yaitu memberikan penilaian dalam buku prestasi peserta didik dan yang terakhir yaitu penutup yang ditutup dengan do'a setelah pembelajaran AlQuran metode Ummi. Media yang digunakan dalam pembelajaran Al-Quran metode Ummi yaitu dengan menggunakan alat peraga Ummi, Al-Quran Ummi, Buku Ummi dan buku prestasi Ummi. Cara guru dalam memberikan pemahamannya dengan cara difahamkan dari pelajaran yang paling mudah dan dengan memberikan contoh-contoh kepada peserta didik.

c. Tahapan Evaluasi Pembelajaran Al Quran metode Ummi di MTs Sunan Drajat Banjarwati Paciran Lamongan.

Untuk Evaluasi penilaian pembelajaran Al-Quran metode Ummi di MTs Sunan Drajat Banjarwati Paciran Lamongan dengan cara awal yang dimulai dari Pre-Test untuk 
mengelompokkan peserta didik sesuai dengan kemampuan peserta didik. (1) Ketika pembelajaran berlangsung di kelas setiap peserta didik mendapatkan penilaian pada buku prestasi peserta didik untuk hasil dari membaca Al-Quran dan pemahaman materi yang telah disampaiakn oleh guru selanjutnya penilaian tentang hafalan Juz 30 yang sesuai dengan terget yang di tentukan, (2) Pengevaluasian setiap 3 bulan sekai yang dilaksanakan pada saat peserta didik UTS dan UAS yang langsung diuji oleh TIM penguji untuk kenaiakn Jilid peserta didik dan tidak semua tingkatan peserta didik sama ada yang Jilid 1,2, dan 3 dan ada juga yang AlQuran sesuai dengan kemampuan peserta didik tersebut, (3) Evaluasi pada saat kelas 3 (Tiga) yaitu Munaqosyah melaksanakan ujian Publik yang langsung disaksikan Wali Murid dan seluruh Ustadz Ustadzah (Khotaman dan Imtihan) dan juga disaksikan langsung oleh seluruh kepala sekolah se-Yayasan Pondok Pesantren Sunan Drajat Lamongan.

Untuk mengenai tindak lanjut manajemen kelas dalam pembelajaran Al-Quran metode Ummi di MTs Sunan Drajat Banjarwati Paciran Lamongan yaitu untuk peserta didik yang tidak lulus dalam pembelajaran Al-Quran metode Ummi diberikan pembelajaran secara privat pada saat setelah KBM (Kegiatan Belajar Mengajar) di madrasah selesai dan untuk peserta didik yang tidak lulus dia sudah dikatakan sukses sudah melampaui pembelajaran Al-Quran metode Ummi ditingkat Jilid satu sudah selesai dan menjadi Jilid tiga dan ada sertifikat sesuai terget yang dicpai untuk peserta didik yang tidak lulus, surat keterangan untuk peserta didik yang lulus dalam pembelajaran Al-Quran .

2. Problematika dan solusi manajemen kelas dalam pembelajaran Al-Quran metode Ummi di MTs Sunan Drajat Banjarwati Paciran Lamongan.

a. Problematika yang terjadi di MTs Sunan Drajat Banjarwati Paciran Lamongan pada saat pembelajaran AlQuran metode Ummi sebagaimana yang telab terjadi selama ini yaitu:

1) Dari pihak madrasah masih membutuhkan tenaga pendidik lebih banyak lagi untuk pembelajaran Al-Quran metode Ummi karena dengan banyaknya jumalah peserta didik yang berada di dalam kelas dan juga menyesuaikan dengan ketentuan yang di tetapkan oleh Ummi Pusat agar bisa menjadikan efektif dan efesien dalam pembelajaran Al-Quran yaitu 1 (Satu) guru maksimal memegang 15-20 pesrta didik sedangkan di MTs Sunan Drajat Banjarwati Paciran Lamongan lamongan 1 (Satu) kelas nya berjumlah 40 peserta didik maka dari pihak madrasah membagi lagi 40 peserta didik dalam 2 (Dua) kelompok untuk pembelajaran Al-Quran metode Ummi.

2) Selanjutnya problem yang dialami oleh pihak madrasah yaitu kurangnya minat belajar peserta didik sangat kurang, sehingga guru sangat sulit untuk bisa mencapai target 100\%.

3) Saat pembelajaran berlangsung banyak siswa yang mengantuk saat pembelajaran dikarenakan banyaknya kegiatan yang ada di pesantren.

4) Tingkat kedisiplinan peserta didik dalam membawa buku panduan metode Ummi masih kurang ada beberapa peserta didik yang tidak membawa.

5) Kurang memperhatikan guru saat pembelajaran berlangsung dan dampaknya kembali kepada peserta didik yang masih belom bisa untuk memahami materi yang telah dijelaskan sebelumnya.

6) pembelajaran yang sudah dikelaskan masing-masing karena lembaga formal beda dengan TPQ (Taman Pendidikan Quran) kalo TPQ bisa langusng naik Jilid langsung dipisah jadi 1 
(Satu) kelompok satu Jilid satu halaman tapi kalau di MTs Sunan Drajat Banjarwati Paciran Lamongan karena kelasnya sudah ditentukan jadi bisa saja nanti satu kelompok ada yang Jilid 1 (Satu),2 (Dua), dan 3 (Tiga) dan ada juga yang Al-Quran jadi kurang efektif pembelajarannya

7) Problem dari peserta didik sendiri yaitu ngantuk saat pemeblajaran Al-Quran metode Ummi karena terkadang hanya disuruh baca saja dan menyimak sedangakan sebelum sampai dipeserta didik yang lainnya kebanyakan peserta didik yang baca di belakang tidur karena terlalu lama menunggu antrian untuk baca.

b. Solusi dalam pembelajaran Al-Quran metode Ummi

Solusi yang harus di pecahkan untuk permasalahan yang ada di atas saat pembelajaran Al-Quran metode Ummi di MTs Sunan Drajat Banjarwati Paciran Lamongan sebagai berikut:

1) Dengan cara dari pihak madrasah harus berani melangkah untuk menambah tenaga pendidik 2 kali lipat terkhusus untuk guru mata pelajaran Al-Quran metode Ummi saja karena melihat kapasitas peserta didik yang begitu banyak jumlahnya.

2) Dan untuk mengatasi permasalahan kurang minatnya belajar peserta didik yaitu dari pihak madrasah harus bisa semampunya untuk memberikan pengajaran yang sesuai untuk peserta didik dengan adanya Koordonator metode Ummi, dan Guru Al-Quran metode Ummi sudah 100\% mengikuti Sertifikasi Guru Al-Quran metode Ummi guna untuk bisa lebih maksimal lagi dalam pembelajaran Al-Quran metode Ummi selain guru yang sudah bersertifiksi guru mengikuti Tahsin setiap satu bulan sekali yang di adakan oleh Korcam dan dari pihak MTs Sunan Drajat Banjarwati Paciran Lamongan sendiri juga mengadsakan Tahsin setiap satu minggu sekali dengan harapan untuk bisa lebih maksimal dalam membimbing peserta didik saat pembelajaran Al-Quran metode Ummi berlangsung.

3) Untuk mengatasi permasalahan yang ke tiga yaitu banyak nya peserta didik yang mengantuk saat pembelajaran Al-Quran metode Ummi berlagusung yaitu dengan cara anggota-anggota kelompok harus diberi kesempatan berpartisipasi dalam pengambilan keputusan yang memberi efek kepada hubungan dan kondisi belajar mengajar berlangsung, membangunkan peserta didik saat tidur ketika kedua kalinya masih saja tidur guru memberikan hukuman dan sanksi kepada peserta didik dengan cara meminta peserta didik untuk wudhu suapaya ngantuk tersebut hilang dan guru harus meningkatkan kedisiplinan peserta didik ketika di dalam kelas.

4) Yang selanjutnya ketika peserta didik tidak membawa buku Jilid atau yang lainnya maka solusi guru dalam menghadapi peserta didik yang seperti ini dengan cara mendahulukan peserta didik yang membawa buku mata pelajaran Al-Quran metode Ummi karena banyak peserta didik yang ingin membaca duluan.

5) Kurangnya psereta didik untuk memperhatikan guru saat pelajaran solusi yang digunakan guru saat permasalahannya seperti ini yaitu dengan cara mengulang materi yang telah dijelaskan dan guru pun juga harus sabar dalam menghadapi peserta didik yang seperti itu.

6) Untuk perbedaan dalam Jilid perkelasnya memang sulit untuk dirubah karena kelasnya tidak bisa dipisah. 
7) Solusi dari permasalahan yang terakhir yaitu dengan cara seperti apa yang telah dijelaskan di atas bahwasanya peserta didik ketika mengantuk langusng disuruh ke kamar mandi untuk wudhu.

\section{Kesimpulan}

\section{Manajemen kelas dalam pembelajaran Al-Quran metode Ummi}

Ada beberapa tahapan yang harus dipersiapakan guru sebelum megelola kelas dalam pembelajaran Al-Quran metode Ummi sebagai berikut:

Perencanaan yang harus dipersiapkan saat pembelajaran Al-Qur'an metode Ummi yaitu semua guru membuat PROTA (Program Tahunan) dan PROMES (Program Semester), mengelompokkan peserta didik yang dilaksanakan saat PPDB (Penerimaan Peserta Didik Baru) yaitu Pre-Test agar bisa mengelompokkan sesuai dengan kemampuan peserta didik. Selanjutnaya mengenai pengorganisasian, sebelum pembelajaran berlangsung guru meminta seluruh peserta didik untuk duduk membentuk later "U" agar pembelajarannya bisa efektif, ketika sudah terbentuk cara duduk peserta didik selanjutnya guru memberikan materi kepada peserta didik sesuai dengan yang telah direncanakan sebelumnya dan pembelajarannya sesuai dengan 7 tahapan yang ditetapkan oleh guru sebelum nya, yang terakhir yaitu Evaluasi guru kepada peserta didik ada 3 pengevaluasiannya (1) disaat pembelajaran berlangsung memberikan penilaian dalam buku prestasi peserta didik dan penilaian hafalan peserta didik (2) penilaian disaat UAS (Ujian Akhir Semester) dan UTS (Ujian Tengah Semester) yang langsung diuji oleh TIM penguji dengan materi kenaiakan jilid peserta didik, (3) pada saat Munaqosyah yang di saksikan langusng oleh TIM penguji, wali murid dan kepala sekolah seYayasan Pondok Pesantren Sunan Drajat Lamongan.

\section{Problem dan Solusi manajemen kelas dalam pembelajaran Al-Quran metode Ummi}

Problem yang terjadi di MTs Sunan Drajat Banjarwati paciran Lamongan saat pembelajaran AlQuran metode Ummi berlangsung yaitu: kurangnya guru dalam pembelajaran Al-Qur'an metode Ummi dengan jumlah peserta didik yang banyak, kurang minatnya peserta didik dalam pembelajaran Al-Quran metode Ummi, banyak peserta didik yang mengantuk saat pembelajaran, tingkat kedisiplinan peserta didik kurang dengan sebagian peserta didik tidak membawa Buku panduan, kurang memperhatikan guru saat pembelajaran berlangsung, dan kurang efektif saat pembelajaran dikarenakan setiap peserta didik dalam 1 kelas ada yang beda jilid. Solusi yang harus dilakukan yaitu pihak lembaga harus berani menambah guru 2 kali saat pembelajaran Al-Quran metode Ummi, guru berusaha untuk bisa menjadikan minat belajar siswa meningkat dengan adanya guru Al-Quran metode Ummi yang sudah bersertifikasi Ummi dan juga mengikuti Tahsin Al-Quran metode Ummi, dengan cara dibangunkan kedua kalinya ketika masih tidur disuruh untuk mengambil air wudlu, mendahulukan peserta didik yang membawa buku panduan, guru harus mengulang kembali materi yang telah dijelaskan sebelumnya dan guru harus sabar, dan untuk problem yang terakhir memang sulit untuk diubah karena satu kelas banyak yang berbeda Jilid.

\section{Daftar Kepustakaan}

Alfi Mufidah Ishari, Wawancara, Pondok Pesantren Putri Sunan Drajat, Tgl 23 Juli 2020, Pada 18.30 WIB. 
Danim Sudarwan dan Yunan Danim. Administrasi Sekolah dan Manajemen Kelas. Bandung: Pustaka Setia. 2010.

Erwin Widiasworo. Cerdas Pengelolaan Kelas. Yogyakarta: DIVA Press. 2018.

Euis Karwati and Donni Juni Priansa. Manajemen Kelas (Classroom Management) Guru Profesional yang Inspiratif, Kreatif, Menyenangkan, dan Berprestasi. Bandung: Alfabeta. 2014.

Faizal Djabidi. Manajemen Pengelolaan Kelas. Malang: Madani. 2016.

Kompri. Manajemen Sekolah: Teori dan Praktik. Bandung: Alfabeta. 2014.

Manna' Al-Qaththanan. Pengantar Studi Ilmu Al-Quran, Terj. Mubabits fi 'Ulumil Qur'an oleb Aunur rafiq ElMåni. Jakarta: Pustaka al-kautsar. 2006.

Mansyuri dan A. Yusuf. Belajar Mudah Membaca Al-Quran Ummi. Surabaya: KPI. 2007.

Mardawani. Praktis Penelitian Kualitatif Teori Dasar dan Analisis Data dalam Prespektif Kualitatif. Yogyakarta, CV Budi Utama, 2020.

Moleong Lexi J. Metodologi Penelitian Kualitatif Edisi Revisi. Bandung: PT Remaja Rosdakarya. 2016.

Sukmadinata Nana Syaodih. Metode Penelitian Pendidikan. Bandung: Remaja Rosdakarya. 2007

Sunaryo. Strategi Belajar Mengajar Ilmu Pengetabuan Sosial. Malang: IKIP Malang.

Syaiful Bahri Djamarah dan Aswan Zain, Strategi Belajar Mengajar. Jakarta: Rineka Cipta, 2002.

Umarti, Hengki Wijaya. Analisis Data Kualitatif Teori Konsep dalam Penelitian Pendidikan. (Makassar: Sekolah Tinggi Theologia Jaffray. 2020. 